\title{
Benefits of Using Traffic Volumes Described on Examples in the Open Transport Net Project Pilot Regions
}

\author{
K. Jedlička ${ }^{1}$, T. Mildorf ${ }^{1}$, K. Charvát ${ }^{2}$, D. Kozhukh², K. Charvát Jr. ${ }^{2}$, J. Martolos $^{3}$, J. Št’astný $^{3}$ \\ ${ }^{1}$ University of West Bohemia, Pilsen, Czech Republic \\ ${ }^{2}$ Help Service - Remote Sensing, Prague, Czech Republic \\ ${ }^{3}$ EDIP Ltd, Pilsen, Czech Republic
}

\begin{abstract}
Anotace
Článek popisuje cíle projektu Open Transport Net v souvislosti s rozvojem pilotních regionů. Zkoumá potenciál dopravních intenzit a jejich možné využití pro rozvoj regionálních dopravních infrastruktur. V úvodu je krátce představen projekt Open Transport Net. Následují popisy zjištěných problémů v pilotních regionech a možnost využití dopravních intenzit $\mathrm{k}$ dosažení kvalitnějších výsledků. Základy výpočtu dopravních intenzit a jejich vizualizace jsou popsány a demonstrovány na př́kladech.
\end{abstract}

\section{Klíčová slova}

Doprava, otevřená data, prostorová data, pilotní regiony, aplikace, dopravní intenzity.

\begin{abstract}
The paper describes the goals of the Open Transport Net project in the pilot regions for regional development and the motivation to use traffic volumes in order to reach the project objectives. In the introduction, a short overview of the Open Transport Net project is provided. It is followed by descriptions of the identified problems in the pilot regions and incentives to use traffic volumes for achieving good quality results. The basics of traffic volumes as well as their visualisation are further described and demonstrated including several examples.
\end{abstract}

\section{Key words}

Transport, open data, spatial data, pilot regions, applications, traffic volumes.

\section{Introduction}

Transport is one of the key issues addressed by EU policy ${ }^{1}$. Europe's population and visitors are reliable on transport and its efficient operation. In order to make it efficient, safe, trusted and sustainable, thorough planning must take place. This is true for example while constructing a new motorway, modifying a road junction, adding an extra connection to a bus line or integrating a train schedule with an online tourist portal. See for examples Yusoff et al. (2014) describing Web-GIS based road management or Zhang, Feng and Gao (2011) describing planning requirements in road network maintenance. A necessary precondition for such planning is the ability to analyse information from the past, combine it with dynamic data coming from sensors such

\footnotetext{
1 See the European Commission's website related to transport at http://ec.europa.eu/transport/index_en.htm
}

as mobile phones as described for example by Goodchild (2011), and to use the generated knowledge for real-time applications and future planning.

The transport also plays a key role in regional development. E.g. Rietveld (1989) states that the importance of transportation infrastructure can be analysed via its impact on interregional trade flows. Regional agencies often order or even directly perform traffic counts and consequent traffic analyses, see e. g. ${ }^{2,3}$. Many studies talking about the influence of transport infrastructure on regional development can be found on google scholar ${ }^{4}$ Looking at first 10 results, all these publications are highly cited (approx.

\footnotetext{
${ }^{2}$ http://www.wmsrdc.org/trafficcounts.html

${ }^{3} \mathrm{http}$ ://tamcmonterey.org/programs/trafficcounts/index.html

${ }^{4} \mathrm{https}$ ://scholar.google.cz/scholar?q=Impact+of+Transport+Infra structure+Investment + on+Regional+Development
} 
$100+$ citations). To mention one reference in particular, there is publication by OECD (2002) called Impact of Transport Infrastructure Investment on Regional Development. Looking in these sources, there can be seen a necessity of available data related transportation and traffic. Opening of such a data is main issue addressed by European project Open Transport Net.

The EU co-funded project Open Transport Net $(\mathrm{OTN})^{5}$, which started in February 2014. Partially OTN aims to support the use of transport data for regional development and public good in general. The main issues that are addressed by this project include:

- supporting the reuse of spatial data in the transport domain,

- combining spatial and non-spatial data from various sources,

- publishing data to enable easy access and data integration with other applications,

- analysing aggregated data and providing new services and visualisations through web interfaces.

The project tackles some technical challenges with data integration and aligning data and services to existing standards. See for example studies of Janečka et al. (2011), Janečka et al. (2013) or Charvat et al. (2014) for best practice examples how to deal with technical and data harmonisation issues during spatial data infrastructure (SDI) development. In addition, the involvement of end users and stakeholders is intensive; social validation makes a valuable contribution to the sustainability of the final results. These results should include:

- data hub for transport data integration and sharing,

- a set of end user applications addressing the main problems in regions and cities,

- validation of these applications in real world scenarios.

OTN focuses on open data that are freely provided by public administration and other organisations. The project started by modelling and visualising traffic volume data that should support transport applications in the OTN pilot areas: regions in the Czech Republic, Belgium, UK and in France. This paper contains the description of user requirements from the pilot regions and a detailed

\footnotetext{
${ }^{5}$ See the project website at http://www.opentransportnet.eu/
}

overview of the traffic volume modelling and visualisation process. Ruston, Mareels and Vaysse (2014) describe in detail the project vision.

\section{Characteristics of and user requirements} of the pilot regions

The OTN project identified the main problems and goals of the OTN pilots through co-design workshops and Ruston \& Lievens (2014) comprehensively developed these workshops in pilot scenarios which are introduced below.

\section{Belgium}

In some Belgium regions, there will be major roadworks carried out between 2014 and 2022. Many roads will be closed. Therefore, there is a need to take some measures that would alleviate the impact of the temporally imposed restrictions (road closures) on transport infrastructure. Such measures can include improvement of public transportation: establishing new public transport links/changing the route of existing links and reducing the time interval between connections. The logic behind is quite simple: the capacity of the public transportation vehicle is generally bigger than the private transportation vehicle, so by making more frequent public transport connections that have reasonably big coverage to bring people where they need, there will be no need for people to use their private transport and thus it will help to prevent transport congestions on roads (because in a public transportation vehicle the ratio of its area and number of passengers that can fit in it is smaller than in a private transportation vehicle).

Together with re-planning public transport some additional measurements could be taken. The number of parking spaces at the edges of the city could be increased. Many people who are commuting to work from other settlements by their private transport and wish later to switch to the public transport should have enough space to park the vehicle when they enter the city. Also infrastructure for cycling could be improved. This can be done through extending the bicycle track networks and creating more places where people could borrow bicycles (this can be classical bike renting places but also some bike sharing systems).

The main OTN project objective in this pilot region will be thus to provide all necessary analytical tools to accomplish these planning tasks. 
There will be some additional minor tasks such as to provide pilot city with visualisation of traffic flows, ongoing roadworks on the map, to create routing web service that will take into account some deduced information from the traffic model as well as live information collected from platform's users' mobile phones or from some external APIs (live information about weather conditions), to create intermodal journey planner that will compute the optimal route from one point to another using the traffic means selected by user.

\section{United Kingdom}

In UK, the main objective is to identify accidentprone segments on motorways. In the future, there can be some steps taken towards decreasing the number of accidents on those segments; for example by setting a new speed limit for cars, put additional traffic lights or restrict the number of parking places. In identifying those segments statistical datasets about traffic accidents from governmental agencies as well as live data from sensors and VGI (volunteered geographical information) will be used. All data about traffic accidents will be merged together and combined with other related datasets; for instance with data about parking lots, speed limits on motorways, traffic volumes (eventually congestions) on motorways. The combination of data will enable deeper analysis. This database of traffic accidents in the city and related data will be maintained by the OTN project and will be available for anyone interested for download.

Furthermore, certain functions such as routing, geocoding, reverse geocoding, finding closest amenity of the certain type will be available for use through restful API. The same basic functions will be available for all the pilots and will use the data stored in the project database. These data can be of a great help to those who want to develop web-applications on top of the OTN data hub.

\section{France}

The national average of time lost in traffic jams in France is 35 hours per a year (Ruston et al. 2014). The government is naturally trying to take some steps to reduce the number of hours its citizens are wasting in traffic jams. For now the city has quite rich public transport network. In addition, there have been established 11 Velib' and 12 Autolib' docks for bicycle and electric-car sharing correspondingly. The role of the OTN in improving the transport situation and commutation from countryside to large cities is mainly relying in launching application that would help users to make more efficient journey plan based on the real-time data about the traffic situation as well as some additional information related to traffic such as current weather conditions. This real-time data can be acquired from data volunteers or from the public and private data providers. In cases when real-time data is missing traffic modelling based on statistical data can be performed in order to estimate the traffic volume at different road segments and take this information in consideration while computing journey plan or routing.

Furthermore, to make transportation of the citizens more efficient the journey plan can include some extra information except just the public transportation routes such as the information about parking lots and Velib'/Autolib' docks. So the user can see for example opportunities to go certain portion of the trip by car then park car in a certain place where there are free parking slots and switch to public transport or for instance go by public transport to certain place and then switch to bicycle in the place of Velib' dock through the intermodal journey planner.

The solution will rely a lot on VGI as well on developing some ways to effectively and promptly share the information between the users of the platform. One such way can be sending to user an SMS notification if there is a traffic accident on the route he has selected in intermodal journey planner. Also all major accidents inputted by users can be twitted through Twitter social network.

\section{The Czech Republic}

The Liberec Region in the Czech Republic will utilise the OTN project for routing rescuers during emergency situations such as flooding. At first, the road network should be extended by field and forest tracks. Then some sources of real time traffic data will be connected to the project database. Possible sources of real time data include:

- weather and hydrological conditions at various hydrometeorological stations throughout the country from the Czech Hydrometeorological Institute,

- actual data about the traffic conditions (ongoing road-works, traffic accidents, traffic jams etc.) from the Road and Motorway Directorate of Czech Republic,

- volunteered geographic information (VGI).

All these data need to be taken into account 
to provide rescuers with as precise routing as possible. The cost of delay in an emergency situation can be high.

\section{Materials and methods}

\section{Traffic volumes and their prediction}

In addition to the routing functionality, which is essential for almost any transport application, there is a need to predict traffic volumes. This should improve the quality of the transport applications in the pilot regions. Martolos and Šindlerová (2013) designed a methodology for traffic volume predictions.

In Belgium, there is a need to take some measures, which were already mentioned above such as change in public transport, arrange more parking lots and improve cycling infrastructure. In order to avoid traffic jams that could happen as a result of multiple road closures due to planned roadworks, there is a strong need to assess traffic volumes and their redistribution over the network. Calculating traffic volumes using short measurements is helpful in these situations. The workflow was described by Martolos and Bartoš (2012).

In United Kingdom, there is a need to analyse factors influencing the location of traffic accidents. An example of such factor can be high traffic volumes at certain road segments. In France and the Czech Republic the need of the traffic modelling is not so obvious because the pilots are mainly dealing with real time data. However, the traffic volumes models can be used to assess the situation on the transport network and to improve quality of the routing service.

In order to compute traffic volumes there is a need to have a well described traffic network. Such a traffic network has to be topologically clean and consistent - to allow routing (see for example the INSPIRE Data Specification on Transport Network $^{6}$ ). Good to know the traffic volumes is particularly true in densely populated areas with big traffic. It is a parameter of a road network which describes the amount of vehicles which go through a network segment in a time period. Together with an information about the maximum capacity of network segments, it can be forecasted where the volume of traffic is going to cause traffic disruptions and traffic jams. We can distinguish three types of traffic volumes:

\footnotetext{
${ }^{6}$ D2.8.I.7 INSPIRE Data Specification on Transport Networks - Guidelines - http://inspire.ec.europa.eu/documents/Data Specifications/INSPIRE_DataSpecification_TN_v3.0.pdf
}

- daily traffic volume (different for each day from Monday to Sunday),

- annual average of daily traffic volume,

- peak traffic volume - in the busiest hour of the day.

A long term predictions can be made calculating the traffic volumes 10,20 or even 30 years into the future.

\section{Input data and parameters}

In general, there are three basic types of data necessary for traffic volume calculation:

- Traffic generators - demographic data about places that are usually represented as points. These points can be cities, city districts or building blocks - it depends on the granularity of the data and the desired level of detail. These data are used for estimation of traffic flows in the network. Distinguishing between different types of places such as living, industrial, service or shopping place is useful for estimation of traffic flows direction changes in time.

- Road network - well defined and topologically correct road network is the fundamental constraining graph structure, which describes the allowed movements between different places.

- Calibration measurements - physical measurements of traffic volumes (traffic censes) at particular spots of the traffic network are used for calibration of calculated volumes.

Process of traffic volume calculation

There exist several tools for traffic modelling, for example EMME, CUBE, PTV VISUM, SATURN, TRANSCAD or OmniTrans. All of them are based on similar principles:

- First of all, the road network topology and consistency have to be checked (deleting pseudo-nodes, cleaning gaps and overlaps). Then junctions are computed and turns defined.

- Then, as the places do not have to lie exactly on a network segment, a connector from each place to the nearest network part (junction or segment) is created. The defined crossing with the network represents a point, in which the people enter the network and generate the traffic.

The two above described points are usually 
realised in a geographic information system (GIS). The following steps are calculated in a transport engineering software:

- Using the demographic data about traffic generators, various types of traffic volumes are calculated, see for example the work of McShane at el (1990) for more details. This step produces relative volumes - it can be visualised which road segment has higher traffic volume then the other.

- Afterwards, those relative volumes are calibrated on absolute values from traffic censuses.

- The final step is an export from a transportation software to a GIS, where the data can be visualised or used together with the rest of geographic data.

\section{Results and discussion}

\section{Traffic volumes in OTN}

The above described peak and daily traffic volumes are useful for crisis management (Liberec Region), ordinary routing (France), road safety analysis (UK) and redirecting of traffic flows (Belgium). Furthermore, regional network reconstructions as well as regional and urban planning can take advantage of long term traffic volume predictions. Therefore, various types of traffic volumes are going to be calculated in the OTN project as a unifying theme which naturally interconnects all four pilots. As the project is still in an early phase (started in February 2014), only a demonstration of traffic volume calculation was prepared.

Traffic network ready for traffic volume calculation

Basic settlement units (source Arc ČR 5007) and a road network from the Road Databank of the Czech Republic were used for the demonstration. The road network is topologically correct with well-defined junctions. First of all, the connectors were calculated (see Figure 1).

\section{Traffic volumes calculated on the road network}

The prepared data were imported into the OmniTrans software. Then the annual and daily volumes were calculated. See Figure 2 for comparison of volumes for different days of a week as an example of time variability of the volumes.

The difference of the traffic volume in an average day hour and a peak hour can be portrayed to see, which road segments are heavily affected by traffic peaks (Figure 3).

Other visualisations can be created. For example a visualisation comparing calculated traffic volumes with the maximum traffic capacity of each segment can detect potential traffic delays and traffic jams. Using long term traffic volumes predictions in urban planning can dramatically improve the quality of live in a city or a region.

${ }^{7}$ ARCDATA PRAHA - http://www.arcdata.cz/produkty-a-sluzby/ geograficka-data/arccr-500/

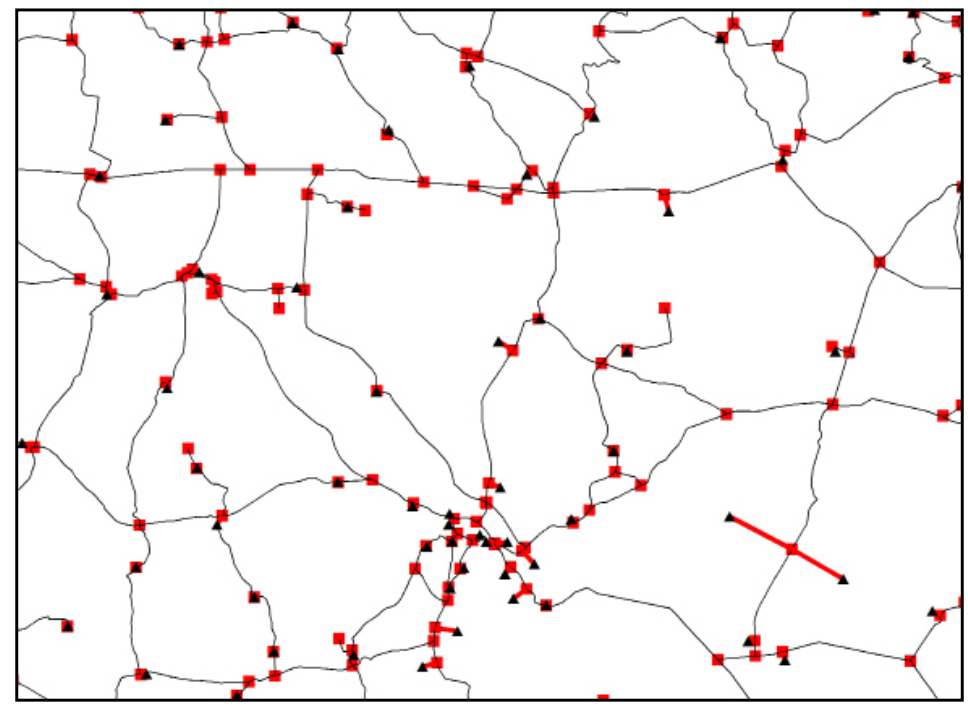

Source: own laboration

Figure 1: Road network (black lines), places (black triangles) and connectors (red lines). 


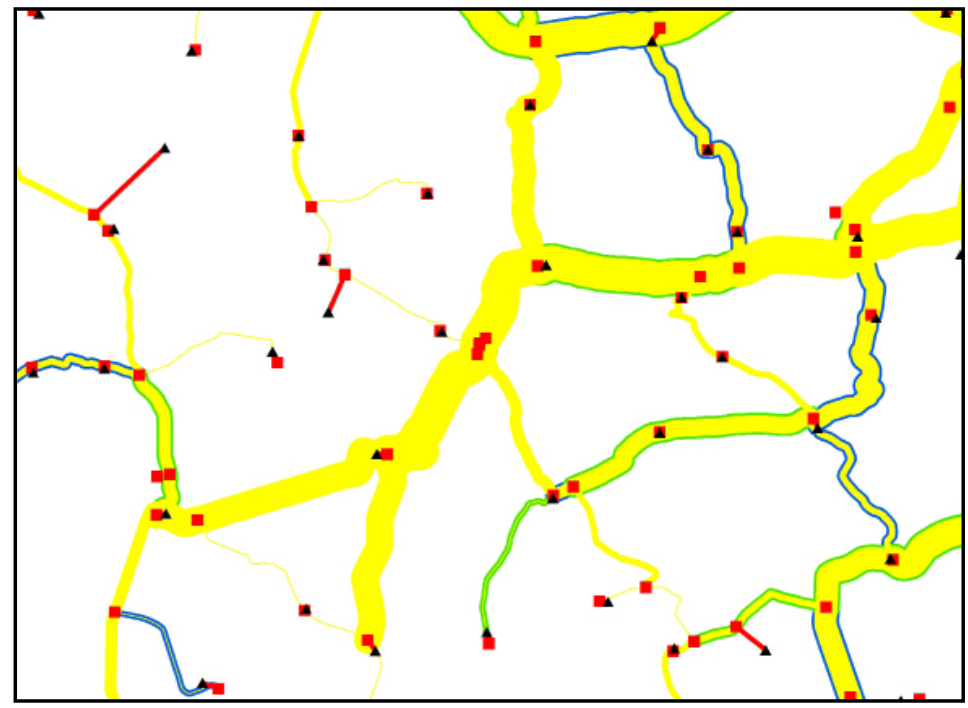

Source: own laboration

Figure 2: Saturday (yellow), week day (green), Friday (blue) traffic volumes displayed using the line segment width..

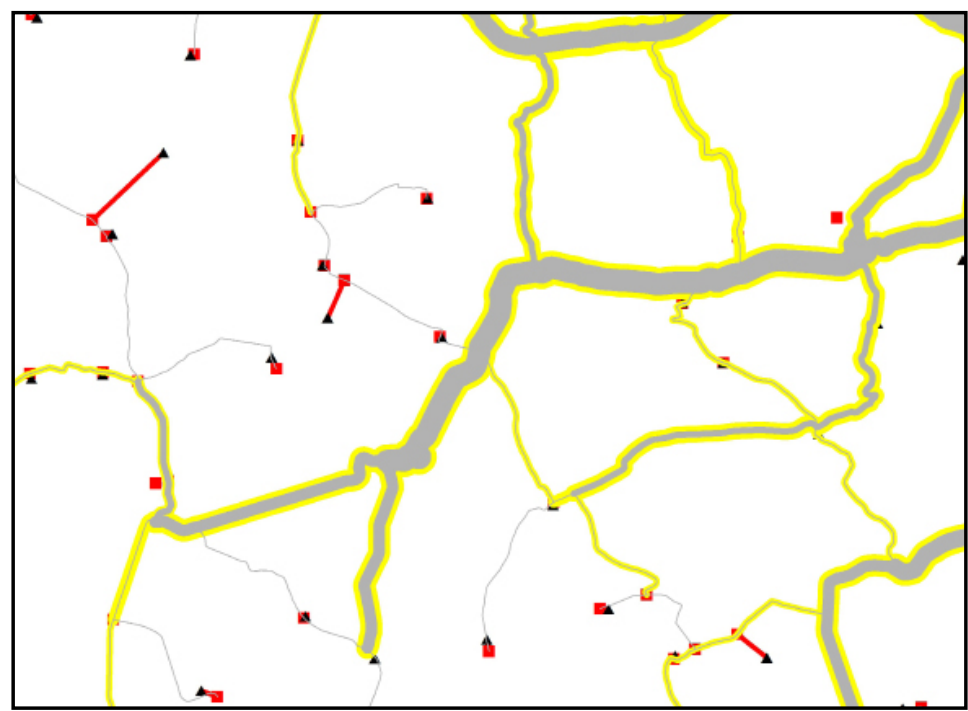

Source: own laboration

Figure 3: Average hourly traffic volume (grey) and peak (yellow) traffic. The thicker line, the heavier peak traffic.

\section{Conclusion}

The article described the main goals of the OTN project in the pilot regions and basics of using traffic volumes. Including traffic volumes into computations could significantly improve the quality of the results of certain operations (for example routing computation, modelling traffic redirection) as well as help to get deeper understanding of events related to traffic (for instance traffic accidents) or even the traffic flow nature in particular region. The modelled traffic volumes can show not only current, but mainly future bottlenecks of regional transportation infrastructure (see the Belgium pilot) and therefore it can be taken into account for future regional transportation infrastructures.

The article will be followed by the practical applications that will be validated through the pilot regions. Based on the achieved results it will be possible to do the real assessment of benefits using the traffic volumes in such computations.

The OTN project aims to increase the use of open 
and geographic data in the transport domain. Transport is essential for various specialisms including forestry and agriculture. The OTN pilot regions serve as test beds for the OTN solution that should be replicable and could be used in other regions and specialisms. For example engineering vehicles such as tractors in agriculture significantly influence the speed and flow of traffic. This usually results in congestions and higher carbon emissions. An application using prediction of traffic volumes could optimise the routes for such vehicles.

\section{Acknowledgements}

The authors of this paper are supported by the European Union's Competitiveness and Innovation Framework Programme under grant agreement no. 620533, project OpenTransportNet. In addition, Karel Jedlička and Tomáš Mildorf are supported by the European Regional Development Fund (ERDF), project "NTIS - New Technologies for the Information Society", European Centre of Excellence, CZ.1.05/1.1.00/02.0090.

Corresponding author:

Dr. Karel Jedlička

University of West Bohemia, Univerzitni 8, 30614 Plzen, Czech Republic

E-mail:smrcek@kma.zcu.cz

\section{References}

[1] Charvat, K., Mildorf, T., Tuchyna, M., Vohnout, P., Krivanek, Z. SDI4Apps. 2014 IST-Africa Conference and Exhibition, IST-Africa 2014, Le Meridien Ile Maurice, Mauritius. 6 May 2014 through 9 May 2014. ISBN: 978-190582444-1.

[2] Goodchild, M. F. Citizens as sensors: The world of volunteered geography. In The Map Reader: Theories of Mapping Practice and Cartographic Representation, eds. Dodge, M., Kitchin, R., Perkins, C., Wiley, London, 2011, p. 370-378. ISBN. 978-0-470-74283-9.

[3] Janečka, K., Berzins, R., Charvát, K., Dzerve, A. On How to Build SDI Using Social Networking Principles in the Scope of Spatial Planning and Vocational Education. Lecture Notes in Computer Science (including subseries Lecture Notes in Artificial Intelligence and Lecture Notes in Bioinformatics), 6783 LNCS (PART 2). 2011, p. 78-92. ISBN 978-3-642-21887-3.

[4] Janečka, K., Čerba, O., Jedlička, K., Ježek, J. Towards interoperability of spatial planning data: 5-steps harmonization Framework. International Multidisciplinary Scientific GeoConference Surveying Geology and Mining Ecology Management, SGEM. June 16-22, 2013, Vol. 1, p. 1005 - 1016. ISBN 978-954-91818-9-0 / ISSN 1314-2704.

[5] Martolos, J., Bartoš, L. Možnosti stanovení návrhových intenzit dopravy na základě krátkodobého měření. Dopravní Inženýrství. Febr. 2, 2012. [On-line] Available: http://www.dopravniinzenyrstvi. cz/clanky/moznosti-stanoveni-navrhovych-intenzit-dopravy-na-zaklade-kratkodobeho-mereni/ [Accessed: 15 Oct. 2014]. ISSN 1801-8890.

[6] Martolos, J., Šindlerová, V. Nová metodika stanovení intenzity generované dopravy. Dopravní Inženýrství. Jan 1, 2013. [On-line] Available: http://www.dopravniinzenyrstvi.cz/clanky/nova -metodika-stanoveni-intenzity-generovane-dopravy/ [Accessed: 15 Oct. 2014]. ISSN 1801-8890.

[7] McShane, W. R., Roess, R. P. Traffic engineering. In Prentice Hall polytechnic series in traffic engineering, Englewood Cliffs, N.J, Prentice-Hall. 1990, p. 643-656. ISBN: 9780139261480.

[8] OECD. Impact of Transport Infrastructure Investment on Regional Development. 2002, p. 152. [On-line] Available: http://www.oecd-ilibrary.org/transport/impact-of-transportinfrastructure-investment-on-regional-development_9789264193529-en [Accessed: 3 Jun. 2015], ISBN: 9789264193529.

[9] Rietveld, P. Infrastructure and regional development. The Annals of Regional Science. 1989, Vol. 23, No. 4, p. 255-274. [On-line] Available: http://link.springer.com/article/10.1007/BF01579778 [Accessed: $3^{\text {rd }}$ Jun. 2015]. ISSN: 1432-0592. 
[10] Ruston, S., Mareels, G., Vaysse, L. Open Transport Network, Deliverable 1.1, Project Vision. 2014. [On-line] Available: http://www.opentransportnet.eu/otn/sites/default/files/OTN_D1.1_Project\%20 Vision_v2.3.pdf [Accessed: 15 Oct. 2014].

[11] Ruston, S., Cave, B., Vaysse, L., Smits, G., Radford, A., Kozuch, D., Charvat, K. (2014). D2.4 Co-design Workshops Reports. 2014, [On-line]: http://opentnet.eu/otn/sites/default/files/OTN\%20 D2.4\%20Co-Design\%20Workshop\%20Reports_v1.0.pdf [Accessed: 15 Oct. 2014].

[12] Ruston, S., Lievens, B. Open Transport Network, Deliverable 2.3, Pilot Scenarios. 2014. [On-line] Available: http://www.opentransportnet.eu/otn/sites/default/files/OTN\%20D2.3\%20 Pilot\%20Scenarios\%20v1_v3.1-4.pdf [Accessed: 15 Oct. 2014].

[13] Yusoff, N. M. R. N., Shafri, H. Z. M., Muniandy, R. An effective road management system using web-based GIS software. IOP Conference Series: Earth and Environmental Science. 2014, Vol. 20, No. 1. Article number 012025. $7^{\text {th }}$ IGRSM International Conference and Exhibition on Remote Sensing and GIS, IGRSM 2014; Kuala Lumpur; Malaysia; 21 April 2014 through 22 April 2014. ISSN: 17551307.

[14] Zhang, H., Feng, Z., Gao, R. Research and development of intelligent decision system for highway maintenance based on GIS. In Proceedings of 2011 International Conference on Electronic and Mechanical Engineering and Information Technology, EMEIT. 2011, Vol. 4, Article number 6023483, p. 1945-1948. ISBN: 978-161284085-7. 